\title{
Pengukuran Pitch dan Intensity Diftong Tertinggi Menggunakan Program PRAAT
}

\author{
Heri Heryono \\ Program Studi S1 Teknik Informatika, Fakultas Teknik, Universitas Widyatama \\ Jl. Cikutra No. 204A, Bandung \\ heri.heryono@widyatama.ac.id
}

\begin{abstract}
Abstrak-Penelitian ini menitikberatkan pada studi kasus sederhana yang melibatkan dua orang pengujar, native dan non-native dalam mengucapkan kata-kata yang mengandung diftong. Bidang linguistik yang terkait adalah fonetik dan fonologi, dengan bantuan sebuah aplikasi PRAAT untuk menghitung frekuensi dan intensitas ujaran. Subjek pembahasan dalam penelitian ini adalah vokal rangkap/diftong (diphthong) yang terdapat dalam beberapa kata berbahasa Inggris. Yang difokuskan hanyalah unsur pitch dan intensity dari dua orang pengujar dalam mengujarkan kata-kata bervokal rangkap tersebut. Metode penelitian yang digunakan dalam mendapatkan perbandingan pitch dan intensity dari dua pengujar ini adalah deskriptif-analisis dengan penyuguhan data berupa tabel angka serta grafik. Penelitian ini melibatkan satu pengujar native dan satu pengujar non-native untuk mendapatkan hasil yang bisa diperbandingkan. Metode pengambilan data menggunakan PRAAT dengan file audio sebagai sumber data utama. Hasil dari penelitian ini menunjukkan bahwa pengujaran diftong dengan nilai pitch tertinggi baik dari pengujar native maupun non-native terlihat pada saat pengujaran kata dengan diftong /ol/; frekuensinya adalah $216.8 \mathrm{~Hz}$ untuk native dan $301.1 \mathrm{~Hz}$ untuk pengujar non-native. Sedangkan untuk intensity, diftong /ı/ memiliki angka intensitas terbesar yaitu 78.36 untuk pengujar native dan 80.52 untuk pengujar non-native. Berdasarkan pengambilan sampel data suara dari dua orang pengujar, maka dapat disimpulkan bahwa diftong /ol/ memiliki frekuensi yang tertinggi dibandingkan lainnya. Dan, diftongp /ı/ memiliki angka intensitas tertinggi dibandingkan dengan diftong lainnya. Penelitian menggunakan PRAAT dengan memperbandingkan pengujar native dan non-native secara fonetis memberikan ruang penelitian baru di ranah Bahasa dan teknologi.
\end{abstract}

Kata kunci-pitch, intensity, diftong, native, non-native

\begin{abstract}
This research focused on a simple case studies involving only two respondents, native and non-native, dealing with pronouncing diphthong words. The related linguistic area for this research were phonetics and phonology, by applying PRAAT application to calculate the frequency and intensity of speech. The subject of the study in this research was diphthongs contained in several English words. The focuses were only the element of pitch and intensity of the two respondents in uttering
\end{abstract}

the diphthong-contained words. The research method used in getting a comparison of pitch and intensity of these two reviewers was descriptive analysis with the presentation of data in the form of numerical tables and graphs. This study involved one native researcher and one non-native researcher to get comparable results. Data retrieval method conducted PRAAT with audio files as the main data source. The results of this study indicated that diphthongs with the highest pitch values from both native and non-native respondents was / or / with a frequency of $216.8 \mathrm{~Hz}$ for native and $202.9 \mathrm{~Hz}$ for non-native. As for intensity, diphthongs / 10 / had the greatest intensity number, 78.36 for native and 80.52 for non-native. Based on the sampling of sound data from two respondents, it could be concluded that diphthongs / o / had the highest frequency compared to other diphthongs. And, / Io / had the highest intensity number compared to other diphthongs. The research by applying PRAAT in comparing native and non-native utterances gave a new space for language and technology area to be explored.

Key words - pitch, intensity, diphthong, native, non-native

\section{Pendahuluan}

Bahasa Inggris telah menjadi kemampuan yang umum diterapkan di institusi akademis dimulai dari tingkat dasar hingga tingkat perguruan tinggi. Pembelajaran Bahasa ke dua (L2) seringkali mendapatkan interfensi dari bahasa ibu (mother tongue), dalam hal ini, bahasa daerah (local language) yang turut andil dalam mempengaruhi pola dan bentuk ujaran pembelajar. Pada dasarnya, suara secara umum dihasilkan melalui dua proses, yaitu generation dan filtering. Proses generation merupakan proses awal suatu bunyi ujaran diproduksi melalui getaran vocal cord serta vocal fold yang terletak pada larynx dalam membentuk dan menghasilkan bunyi periodik. [11] Dalam sistem kebahasaan, ujaran merupakan salah satu hal yang paling mendasar untuk menentukan terjadinya komunikasi. Bunyi periodik yang bersifat konstan, memungkinkan terjadinya filtrasi suara yang kemudian dialirkan melalui articulator yang terdiri dari gigi, bibir, lidah langit-langit dan lain sebagainya. Hal itu yang memunculakn adanya sebuah bunyi output atau luaran. [12] Bunyi luaran tersebut 
dapat berupa vokal atau konsonan, dan kecenderungan dalam berkomunikasi dalam bentuk ujaran adalah dengan menghasilkan dua jenis bunyi tersebut dalam sebuah kombinasi. Luaran seperti inilah yang bisa dijadikan sebagai sumber data dalam beberapa penelitian terkait Fonetik\&Fonologi.

Analisis bunyi ujaran dapat menghasilkan output lain, terutama dalam bidang teknologi. Sehingga, dengan adanya penelitian di bidang Fonetik, muncul beberapa program voice recognition programs, seperti Voice Control yang diperkenalkan oleh Apple, atau Google Voice yang dipakai oleh Google, serta beberapa VR yang diterapkan di perusahaan otomotif, seperti Voice Command di mobil Wuling dan DFSK untuk fitur pengoperasioan berbasis suara (voice).

Dalam sistem bunyi ujaran, terdapat beberapa hal yang memungkinkan untuk dianalisis, seperti adanya frekuensi dan pitch yang berbeda di tiap pengujar. Dalam hal ini, pengujar native dan non-native akan memiliki pitch yang tentunya berbeda dalam mengucapkan satu kata yang sama. Namun dalam pengukuran besarnya frekuensi atau decibel yang dikeluarkan oleh pengujar, diperlukan sebuah metode pengambilan dan pengukuran sampel data yang akurat. Ketinggian pitch dan juga intensity dalam ujaran terutama mudah diukur dengan kata yang memiliki vokal rangkap, atau diphthong. Dan hal inilah yang diguanakan dalam penelitian ini untuk mengukur frekuensi dan intensitas suara dalam pengujaran kata. Analisis yang dilakukan adalah berupa contrastive analysis sebagai upaya untuk mengamati perbedaan, penyimpangan atau kekeliruan dalam mengujarkan suatu kata. [5] Software terkait yang digunakan dalam penelitian ini adalah PRAAT yang merupakan sebuah program fonetik untuk menganalisis bunyi ujaran, meskipun ujaran tersebut bersifat manipulative. Aplikasi PRAAT menyediakan fitur untuk merekam suara secara langsung menggunakan device yang telah terinstal, namun masih computer-based program, sehingga belum available untuk mobile. Setelah mendapatkan rekaman suara, PRAAT kemudian bisa membedah suara tersebut menjadi spectogram yang detail dan menghasilkan bagian-bagian tersendiri yang lebih detil dari suara tersebut. Spectogram terdiri dari frekuensi low dan high yang berupa sinyal suara. Selain itu juga memungkinkan untuk mengukur pitch, intensity serta formant suara secara menyeluruh dan memunculkan grafik untuk menggambarkan hasilnya. [3] Dalam Penelitian ini, analisis yang dilakukan hanya terhadap vokal rangkap saja atau diphthongs yang merupakan bunyi umum yang ada dalam kosakata Bahasa Inggris maupun Bahasa Indonesia, sehingga kecenderungan dalam kesalahan ujaran bias sedikit teratasi. Terutama bagi pengujar non-native dengan latar belakang budaya Bahasa Sunda, terbiasa mengujarkan diphthong dalam kosakata. Pada dasarnya, diphthong itu sendiri merupakan bunyi glide dari dua buah vokal dengan cara berpindah posisi. [8] Diwakili dengan adanya kemunculan dua vokal sekaligus (rangkap) dalam satu kata. Pembatasan jumlah diphthong yang digunakan sebagai data dalam penelitian ini hanya lima kata/kosakata dalam Bahasa Inggris. Kedua pengujar sama-sama mengucapkan lima buah kata yang sama untuk melihat perbedaan dan menghitung frekuensi serta intensitas tertinggi yang diperoleh pada saat reponden mengujarkan kata-kata tersebut. Hal ini bisa menjadi acuan bagi pengujar nonnative dalam mengucapkan kata yang bersifat native-like, sehingga kemungkinan mengalami kekeliruan luaran bunyi dan perbedaan makna akan diminalisir.

Hal lainnya adalah intonasi ujaran, yang terkadang berragam di kalangan pengujar, bahkan dalam mengucapkan kata yang sama, kecenderungan untuk berbeda intonasi selalu ada. Beberapa orang selalu berakhir dengan intonasi turun dalam mengujarkan kata, namun yang lainnya memilih intonasi naik dalam mengakhiri pengucapan kata.

\section{PENELITIAN TERKAIT}

Metode penghitungan pitch dan intensity secara umum diperoleh dari bunyi diftong dan vokal yang terdapat pada ujaran. [16] Penelitian lainnya yang terkait dengan metode pengukuran syllable dalam penggunaan PRAAT menghasilkan speech rate. [15] Metode pengukuran diftong di area vowel dispersion menunjukkan adanya jarak dalam pengujaran diftong yang terjadi saat mengujarkan Bahasa Inggris. [10] Dalam bidang ilmu forensik, PRAAT juga dijadikan sebagai alat ukur kemiripan dan keakurasian suara untuk memperoleh informasi terkait barang bukti berupa suara. [1] PRAAT dapat diaplikasikan sebagai penelitian dalam pengajaran (kelas) dengan konsep CALL (computer assisted language learning) sebagai medianya. [6] Dalam penggunaan PRAAT, ada segmentasi yang membantu menghasilkan deretan angka frekuensi dan intensitas yang lebih rinci, sehingga outputnya berupa textgrid annotation. [2] Dalam hal penghitungan frekuensi dan intensitas suara, jenis kelamin menentukan perbedaan hasil. [14]

\section{DIPHTHONG, PITCH DAN INTENSITY}

Pengukuran frekuensi dan intensitas dalam penelitian ini berfokus pada kata-kata dengan vocal rangkap (diphthongs) yang terkandung didalamnya. Penelitian ini menggunakan lima kata yang mengandung diphthongs dengan lima macam diphthong yang berbeda. Penggunaan PRAAT di dalam jurnal ini membantu menganalisis ukuran frekuensi (pitch) dan intensitas ujaran, sehingga hasilnya berupa angka dalam satuan $\mathrm{Hz}$ untuk pitch dan $\mathrm{dB}$ untuk intensity. 


\section{A. Diphthong}

Dalam ilmu Fonetik, diftong (dhipthong) dikategorikan sebagai bunyi yang kecenderungan memiliki panjang ujaran yang berbeda dengan vokal tunggal. Diftong juga dibedakan jenisnya menjadi dua jenis, yaitu diftong naik dan diftong turun. Perbedaan diantara keduanya adalah, posisi bunyi yang keluar saat diftong tersebut diujarkan. Diftong naik terjadi karena bunyi awal posisinya lebih rendah dari posisi bunyi yang kedua. Sementara diftong turun yaitu bunyi awal posisinya lebih tinggi dibanding bunyi yang kedua. [8]

Dalam bahasa Inggris, umumnya diftong terbagi menjadi 8 jenis; yaitu /eI/, /aI/, /oI/, /ıə/, /eə/, /av/, /ov/ dan /və/ dengan karakteristik frekuensi dan intensitas ujaran yang berbeda. Pada dasarnya, penelitian terkait diftong memiliki banyak variasi kombinasi; karena diftong akan selalu berkaitan dengan dialek, aksen, bahasa asli dan juga latar belakang budaya. Dengan kata lain, penelitian terkait diftong akan memunculkan variasi sub-penelitian lain yang akan saling terkait. Dalam penelitian ini, diftong yang dipakai sebagai acuan adalah diftong dalam bahasa Inggris. Jumlah diftong yang digunakan sebagai data dalam penelitian ini hanya dibatasi pada lima diftong dengan penerapan program PRAAT dalam mengukur detil frekuensi dan intensitasnya.

Berbeda dengan vokal tunggal (monophthong) yang cara pengucapannya dibagi menjadi tiga: close, half-close dan open; diftong hanya dibagi menjadi dua, yaitu centring dan closing. Pembagian tersebut ditampilkan lebih detil pada gambar bagan diftong di bawah ini:

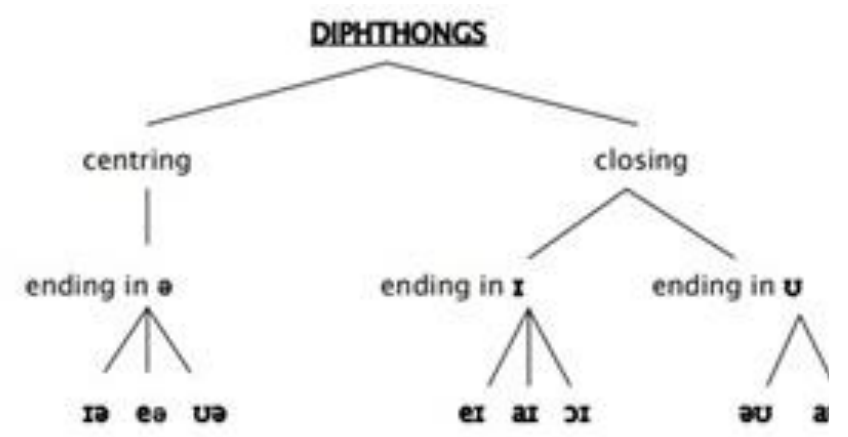

Gambar 1. Bagan diftong

Dalam gambar tersebut, terdapat dua jenis diftong; centring dan closing. Diftong jenis centring merupakan bunyi yang sifatnya gliding dengan huruf /o/ (schwa), seperti yang terlihat di dalam diagram di atas. Yang termasuk pada diftong ini adalah: /ı/, seperti dalam contoh kata bit, bin. Kemudian vocal /eə/, seperti pada contoh kata get, men. Dan vocal /və/ seperti pada kata put, pull.

Jenis diftong kedua yaitu closing; yang merupakan bunyi vocal saat gerakan lidah terjadi dari posisi central low menuju posisi yang lebih tinggi. Contoh diftong dengan kategori ini adalah /eI/, /aI/, dan /oI/ untuk yang berakhiran I, serta /əo/ dan /av/ untuk berakhiran $\mho$.

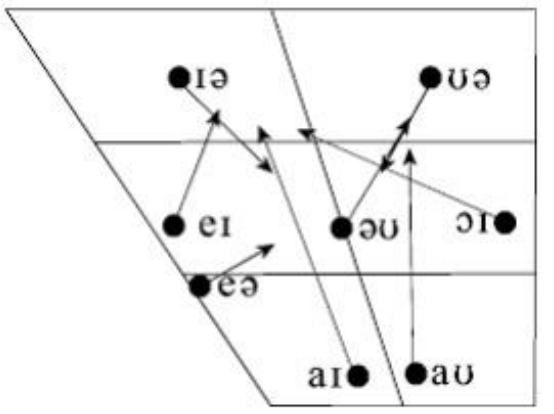

Gambar 2. Diagram bunyi diftong dalam bahasa Inggris

Dalam Fonetik, kemampuan pengujar non-native dalam mengucapkan kata yang mengandung diftong akan dipengaruhi oleh kemampuan fonologis yang masih dipengaruhi oleh mother tongue. Sehingga pengujaran diftong tidak akan seperti yang digambarkan pada diagram bunyi di gambar 2 tersebut. [4]

\section{B. PRAAT}

Pengguna dapat langsung mengaplikasikan data suara pada program ini tanpa harus mengekstraksi atau mengkonversi file suara tersebut asalkan format audio sudah berbentuk wav untuk memudahkan proses analisis. Terdapat dua bagian display kosong saat program PRAAT pertama kali dibuka; display pertama untuk menginput file audio dan display kedua diperuntukkan sebagai area grafik hasil analisis. Gambar di bawah ini merupakan tampilan awal PRAAT. [13]
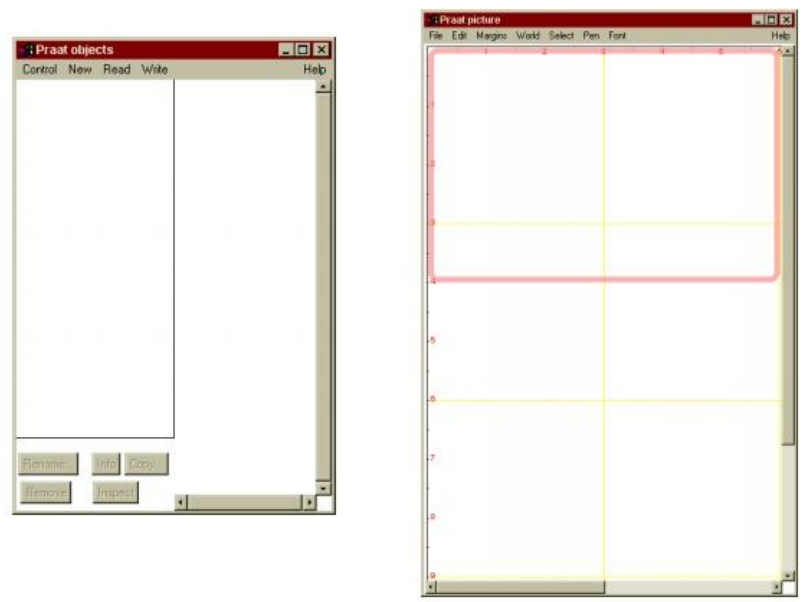

Gambar 3. Tampilan awal user interface PRAAT

\section{Pitch}

Pada prinsipnya, bunyi ujaran terdiri atas beberapa komponen, yaitu formant, pitch, intensity yang dapat digunakan untuk mengidentifikasi karakteristik seseorang untuk kepentingan voice recognition. Dalam kaitannya dengan frekuensi suara, pitch memegang peranan utama dalam mengukur berapa frekuensi suara pengujar dalam 
mengucapkan kata. Setiap manusia memiliki pitch yang bervariasi dan berbeda sehingga menjadi kekhasan. Hal ini dipengaruhi oleh aspek fisiologis dari larynx yang memiliki perbedaan. Dalam kondisi normal, level habitual pitch berkisar antara $50-250 \mathrm{~Hz}$ untuk laki-laki dan $120-500 \mathrm{~Hz}$ untuk perempuan. Hal ini secara linguistik dapat dipergunakan untuk menganalisis kondisi sesorang dalam hal intonasi, berkaitan dengan emosi. [9] Dalam PRAAT, ada pengaturan yang memungkinkan peneliti dapat menghitung pitch suara sesorang yang telah dimasukkan sebagai sumber data untuk analisis di program tersebut. Tanda pitch dalam PRAAT berwarna biru dengan nilai yang terpampang di sebelah kanan.

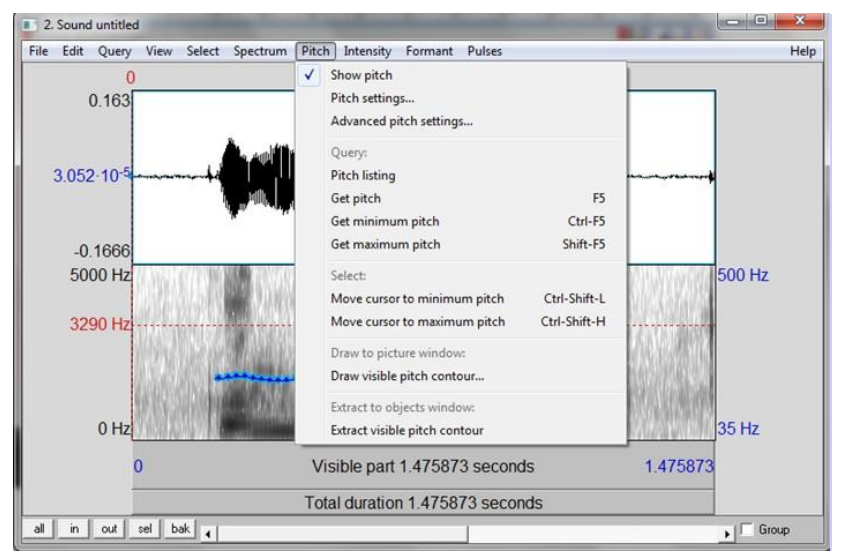

Gambar 5. Menu untuk Pitch dalam PRAAT

Untuk mendapatkan informasi mengenai besaran angka pitch, pengguna bias mengklik get pitch dengan sebelumnya mengaktifkan (ceklis) show pitch.

\section{Intensity}

Dalam Fonetik, intensity merupakan gelombang suara yang diukur dengan satuan dB (decibels) dan sebagai indikator seberapa kuat suara tersebut berbunyi. [7] Dalam PRAAT, intensity berfungsi untuk mengektraksi suara menjadi decibels. Intensity memiliki warna kuning dengan garis tegas dan nilai/ukuran dari intensitasnya bias diperoleh dengan mengklik menu get intensity list pada menu intensity.

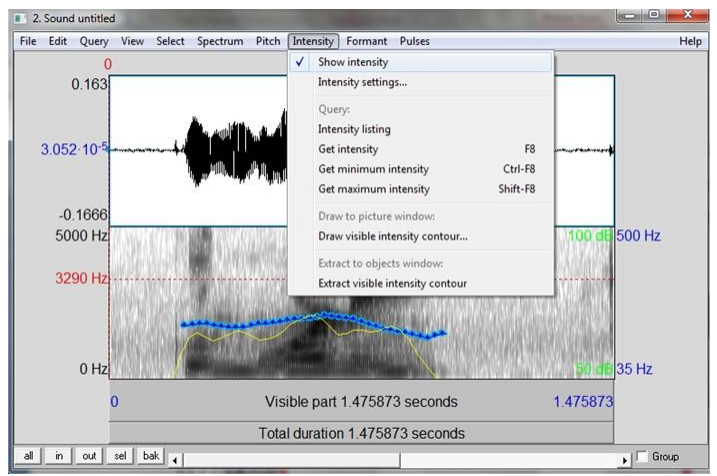

Gambar 6. Menu untuk Intensity dalam PRAAT

Seperti yang terlihat pada gambar 6, yang merupakan menu untuk pemerolehan data intensity dari sebuah file suara yang sudah diinputkan ke dalam program PRAAT. Terlihat garis kuning tegas sebagai penanda bahwa intensity suara yang diproses dalam PRAAT memiliki gelombang suara seperti yang ditunjukkan tersebut.

\section{HASIL DAN PEMBAHASAN}

Dari hasil analisis dengan menggunakan program PRAAT, dari kedua narasuara, penelitian ini menunjukkan perbandingan perbedaan pitch dan intensity dari kedua narasuara. Baik responden native maupun non-native merupakan responden berjenis kelamin perempuan dengan range suara yang hampir sama. Penelitian ini menggunakan lima buah kata berbahasa Inggris yang diujarkan oleh kedua responden dengan cara direkam.

\section{A. Analisis Data Penelitian}

Analisis dilakukan pada output suara responden dalam mengujarkan lima kata berisi diftong yang memiliki karakteristik frekuensi dan intensitas berbeda. Hasil data berupa analisis besaran frekuensi dan intensitas suara yang ditampilkan dalam bentuk tabel serta grafik. Secara garis besar, hasil analisis dengan menggunakan PRAAT menghasilkan rincian data sebagai berikut:

Tabel 1. Data pitch dan intensity pengujar native

\begin{tabular}{|c|c|c|c|c|c|}
\hline $\begin{array}{c}\text { No } \\
\text {. }\end{array}$ & $\begin{array}{c}\text { Dph } \\
\text { t }\end{array}$ & $\begin{array}{c}\text { Wor } \\
\text { d }\end{array}$ & Trns & $\begin{array}{c}\text { Pitch } \\
(\mathrm{Hz})\end{array}$ & $\begin{array}{c}\text { Intensity } \\
\text { (dB) }\end{array}$ \\
\hline 1 & /eI/ & chair & $/ \mathrm{f} \varepsilon \mathrm{r} /$ & 210.6 & 76.85 \\
\hline 2 & /19/ & here & /hir/ & 189.2 & 78.36 \\
\hline 3 & /ai/ & mine & /main & 211.4 & 73.3 \\
\hline 4 & $/ \mathrm{oI} /$ & boy & /bor/ & 216.8 & 71.38 \\
\hline 5 & /ชə/ & cure & /kjor/ & 188.1 & 75.78 \\
\hline
\end{tabular}

Berdasarkan tabel di atas, terlihat detil dari besaran frekuensi dalam satuan $\mathrm{Hz}$, sedangkan intensitas dalam satuan dB. Kata yang dijadikan sumber data adalah chair, here, mine, boy dan cure. Dalam tabel tersebut juga ditampilkan transkripsi dari kata-kata yang mengandung diftong, sehingga terlihat cara membacanya. Kolom bertanda $N$ menunjukkan data result untuk native, sedangkan $n N$ berarti non-native. Angka-angka yang terpampang pada tabel tersebut merupakan hasil pemerolehan menggunakan PRAAT. Kedua responden adalah perempuan dengan latar belakang Bahasa ibu (mother tongue) yang berbeda, namun memiliki kemiripan pitch dan intonasi. Untuk mendapatkan hasil yang lebih akurat, penelitian ini dilakukan; sehingga perbedaannya 
dapat terlihat dengan representasi angka-angka sebagai acuannya.

\section{B. Pitch dan Intensity untuk pengujar Native}

Dari hasil penelitian menunjukkan bahwa pengujaran kata-kata dibawah ini memunculkan spectrogram dan grafik yang bervariasi, berdasarkan diftong yang terkandung di dalamnya. Beberapa penelitian telah mengukur vowel duration dengan menggunakan PRAAT dan menghasilkan luaran berupa spectrogram sebagai berikut:

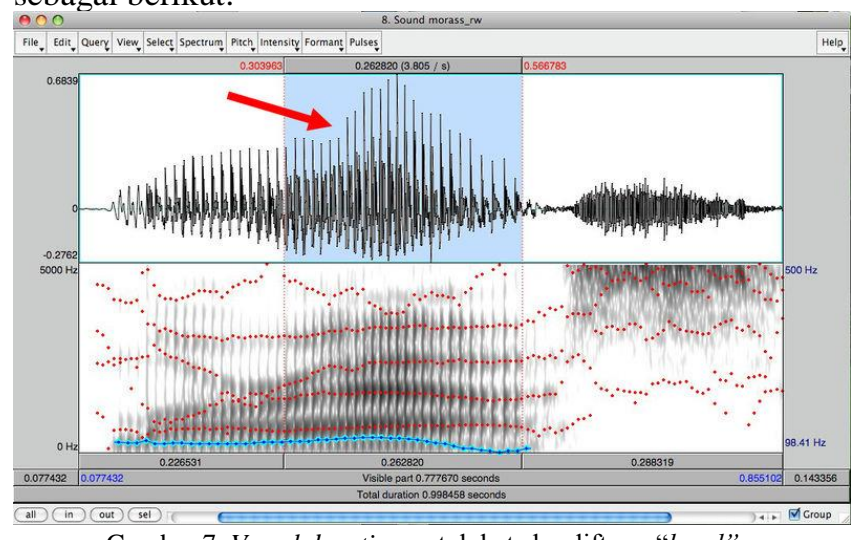

Gambar 7. Vowel duration untuk kata berdiftong "bead"

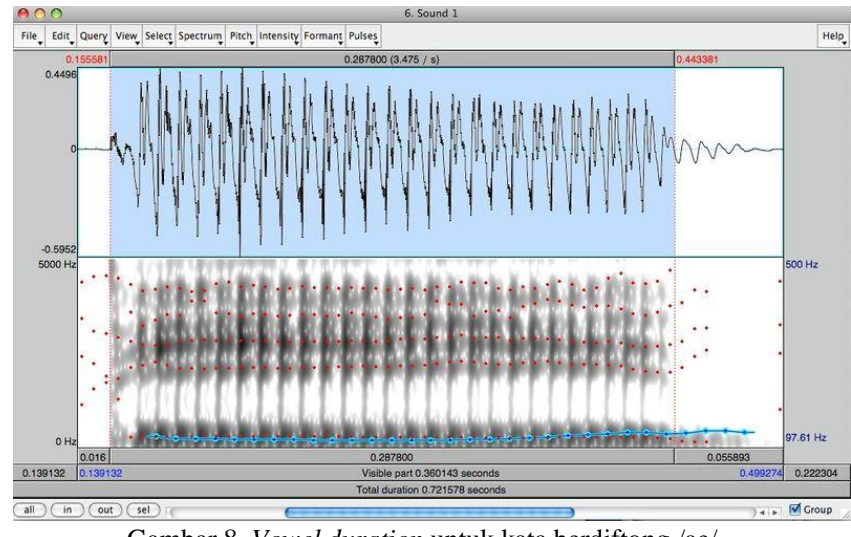

Gambar 8. Vowel duration untuk kata berdiftong /ae/

Dalam luaran spectrogram tersebut, pengukuran yang dilakukan kepada diftong melibatkan formant dan juga durasi dari vokal yang diujarkan.

Berbeda dengan penelitian yang telah dilakukan sebelumnya, pada penelitian ini, pengukuran diftong lebih focus pada pitch serta intensitas dari diftong yang diujarkan oleh pengujar, native dan non-native.

Berikut adalah hasil dari pengukuran pitch dan intensity pada beberapa diftong yang telah dilakukan dengan penyajian data berupa grafik serta spectrogram.

1. Chair/eI/

Pada pengujar native, kata chair memiliki properti pitch $210 \mathrm{~Hz}$, dan intensity $76.85 \mathrm{~dB}$.
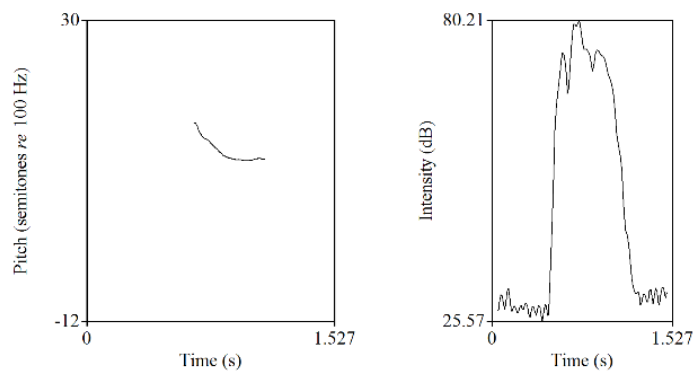

Gambar 9. Grafik untuk pitch dan intensity kata chair

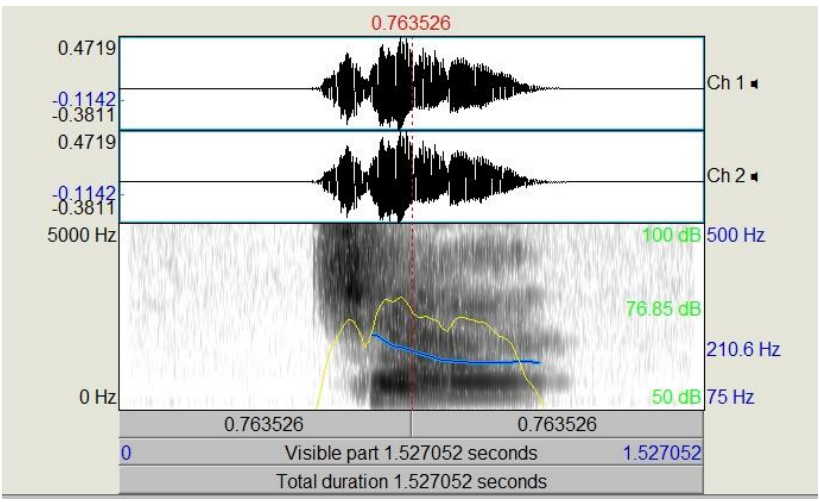

Gambar 10. Spectogram kata chair

2. Here/1ә/

Pada pengujar native, kata chair memiliki properti pitch $189.2 \mathrm{~Hz}$, dan intensity $78.36 \mathrm{~dB}$.
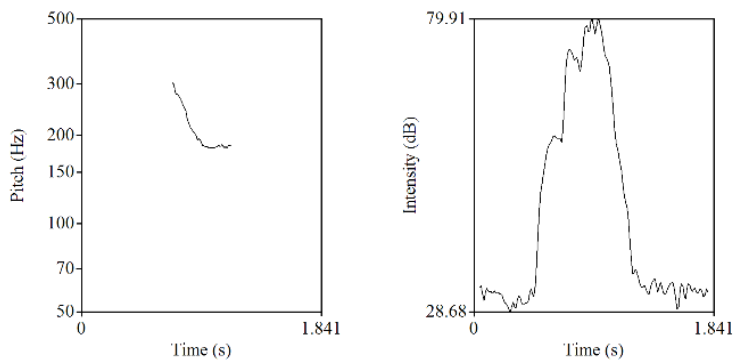

Gambar 11. Grafik untuk pitch dan intensity kata here 


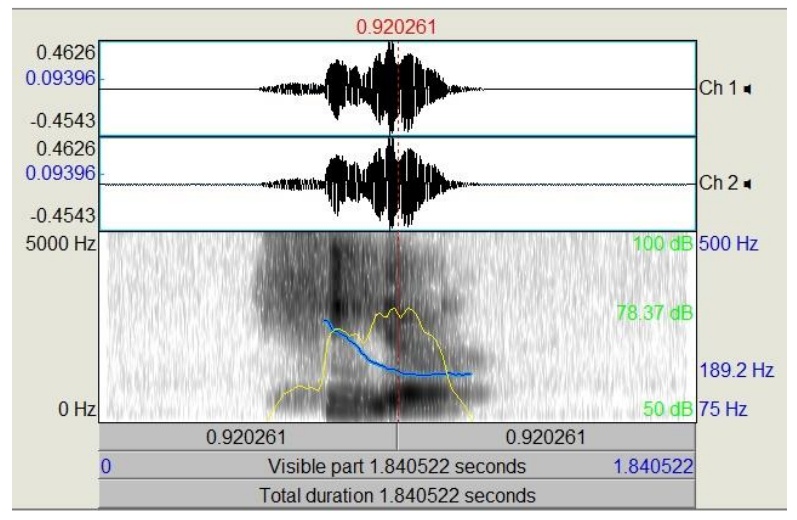

Gambar 12. Spectogram kata here

3. Main /aI/

Pada pengujar native, kata main memiliki properti pitch $211.4 \mathrm{~Hz}$ dan intensity $73.3 \mathrm{~dB}$.
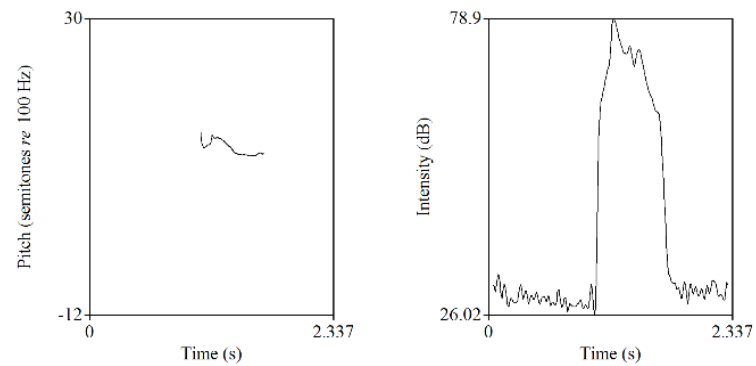

Gambar 13. Grafik untuk pitch dan intensity kata mine

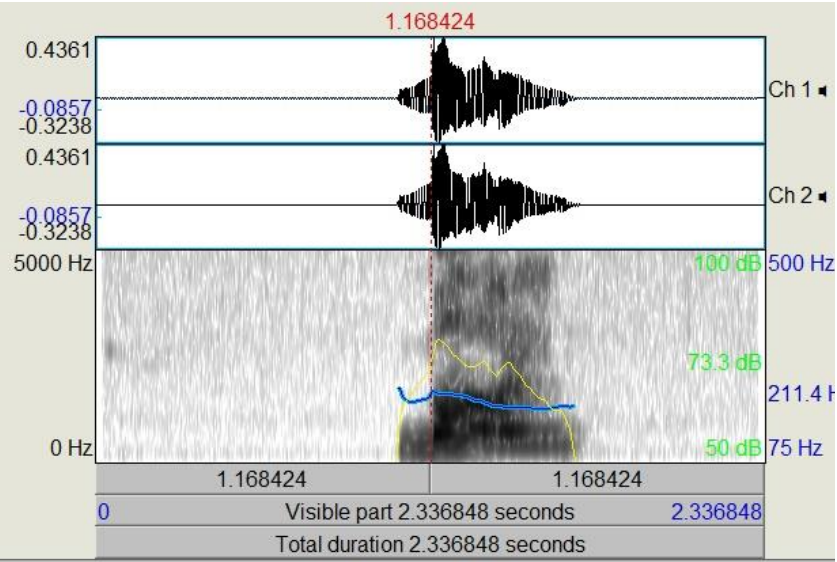

Gambar 14. Spectogram kata mine

4. Boy /oi $/$

Pada pengujar native, kata main memiliki properti pitch $216.8 \mathrm{~Hz}$ dan intensity $71.38 \mathrm{~dB}$.
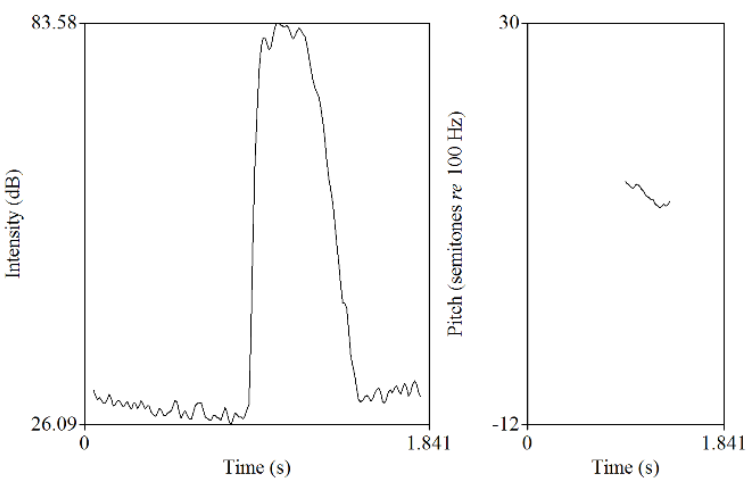

Gambar 15. Grafik untuk pitch dan intensity kata boy

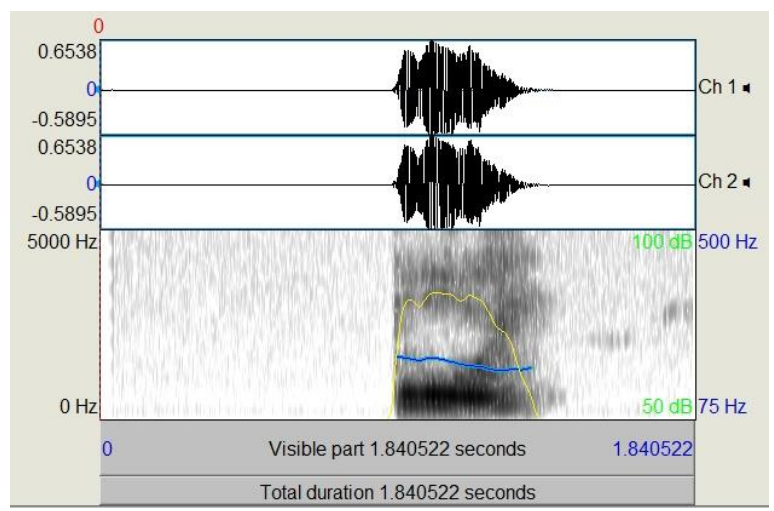

Gambar 16. Spectogram kata boy

Jika dibandingkan dengan penelitian yang telah dilakukan sebelumnya, tampilan PRAAT dalam mengukur diftong tersebut adalah:

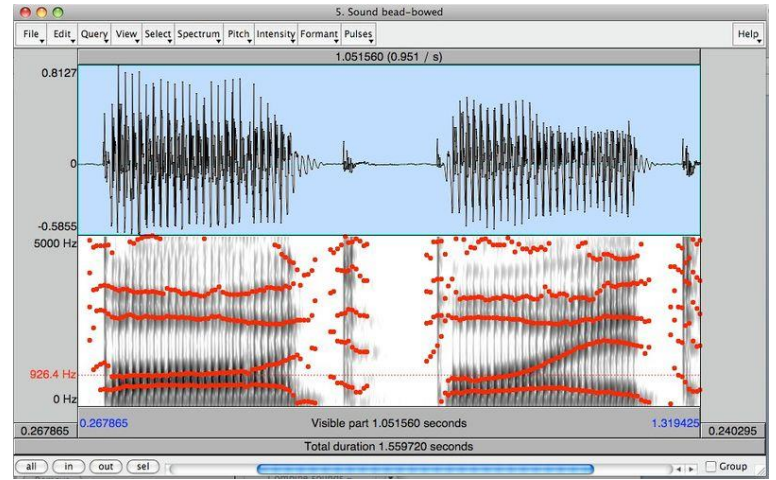

Gambar 17. Grafik untuk pitch dan intensity kata cure

5. Cure /vo/

Pada pengujar native, kata main memiliki properti pitch $188.1 \mathrm{~Hz}$ dan intensity $75.78 \mathrm{~dB}$. 

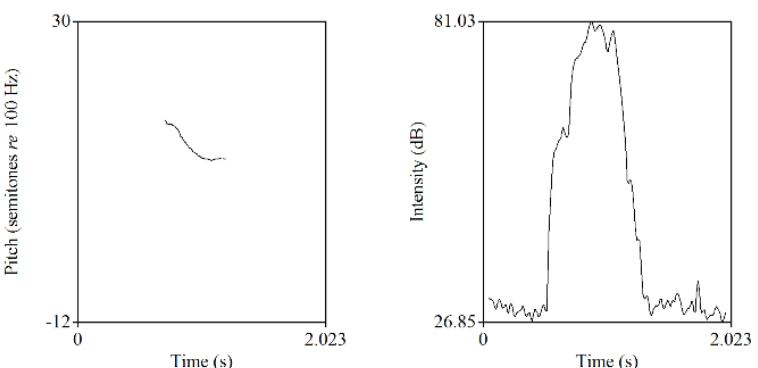

Gambar 18. Grafik untuk pitch dan intensity kata cure

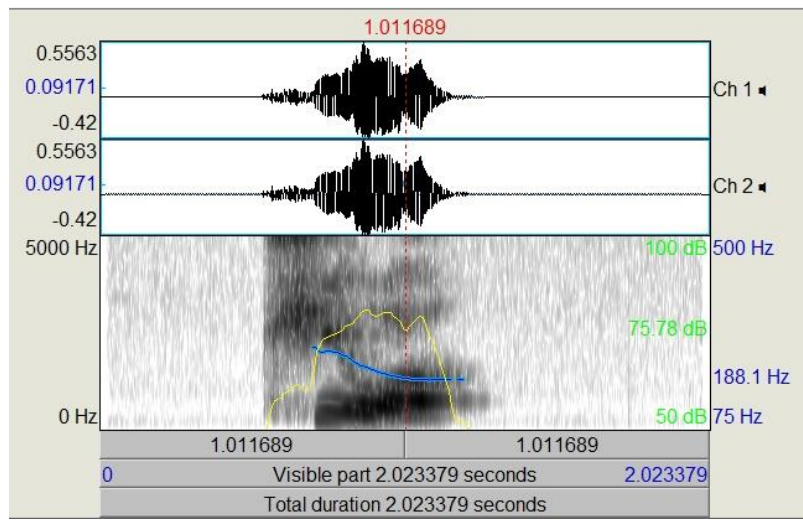

Gambar 19. Spectogram kata cure

C. Pitch dan Intensity untuk pengujar non-Native

Dari hasil penelitian menunjukkan bahwa pengujaran kata-kata dibawah ini memunculkan spectrogram dan grafik yang bervariasi, berdasarkan diftong yang terkandung di dalamnya.

Tabel 2. Data pitch dan intensity pengujar non-native

\begin{tabular}{|c|c|c|c|c|c|}
\hline No. & Dpht & Word & Trns & Pitch $(\mathrm{Hz})$ & $\begin{array}{c}\text { Intensity } \\
\text { (dB) }\end{array}$ \\
\hline 1 & $/ \mathrm{ei} /$ & chair & $/ \mathrm{t} \varepsilon \mathrm{r} /$ & 204.9 & 75.52 \\
\hline 2 & /Іә/ & here & /hir/ & 214.9 & 80.52 \\
\hline 3 & /ai/ & mine & /main/ & 212.5 & 79.13 \\
\hline 4 & $/ \mathrm{JI} /$ & boy & /boi/ & 301.0 & 76.12 \\
\hline 5 & /๘ə/ & cure & /kjor/ & 202.9 & 79.06 \\
\hline
\end{tabular}

1. Chair /eI/

Pada pengujar non-native, kata chair memiliki property pitch $204.9 \mathrm{~Hz}$ dan intensity $76.85 \mathrm{~dB}$.
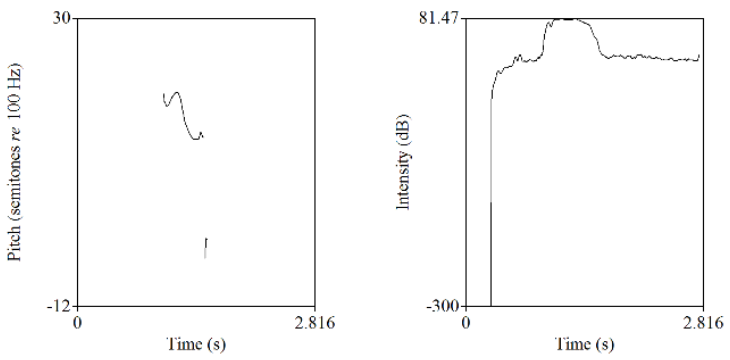

Gambar 20. Grafik untuk pitch dan intensity kata chair $(n N)$

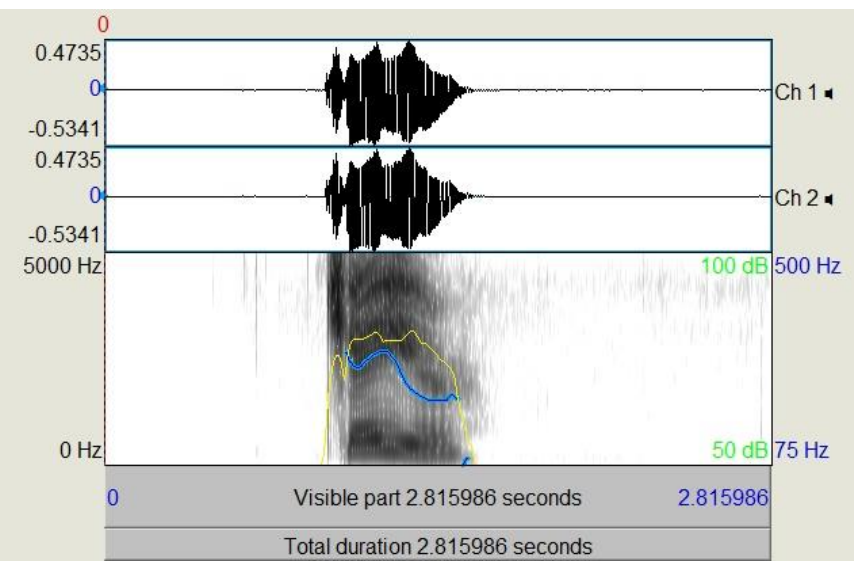

Gambar 21. Spectogram kata chair

2. Here /ı/

Pada pengujar non-native, kata here memiliki property pitch $214.9 \mathrm{~Hz}$ dan intensity $80.52 \mathrm{~dB}$.
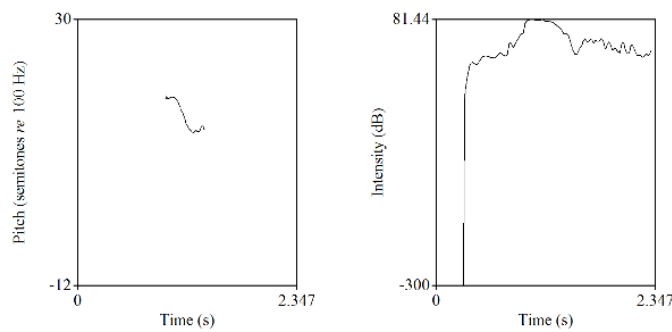

Gambar 22. Grafik untuk pitch dan intensity kata here $(n N)$

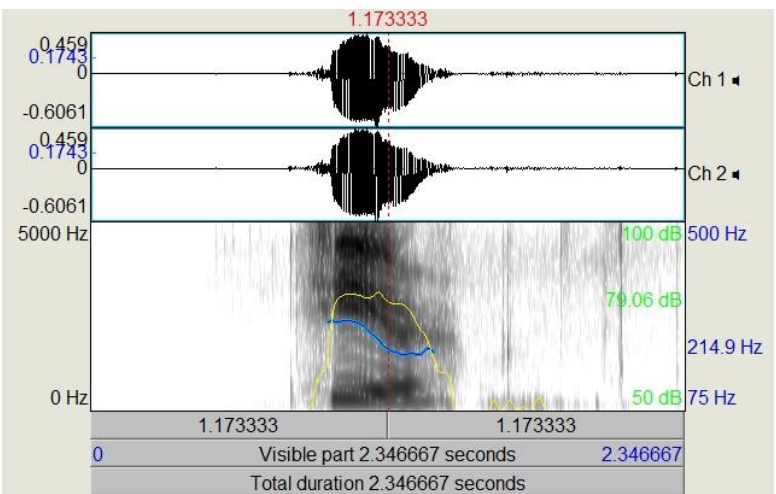

Gambar 23. Spectogram kata here 
3. Mine /ai/

Pada pengujar non-native, kata mine memiliki property pitch $212.5 \mathrm{~Hz}$ dan intensity $79.13 \mathrm{~dB}$.
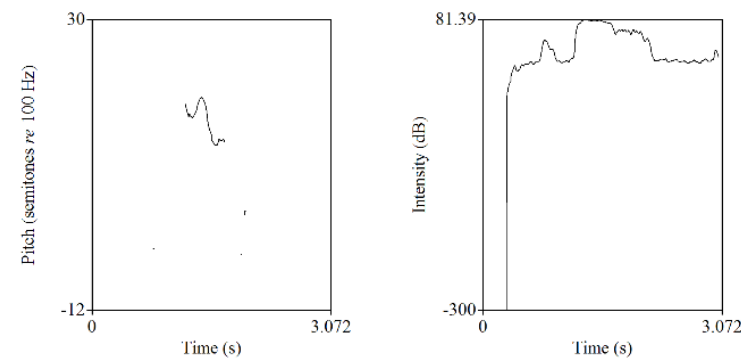

Gambar 24. Grafik untuk pitch dan intensity kata mine $(n N)$

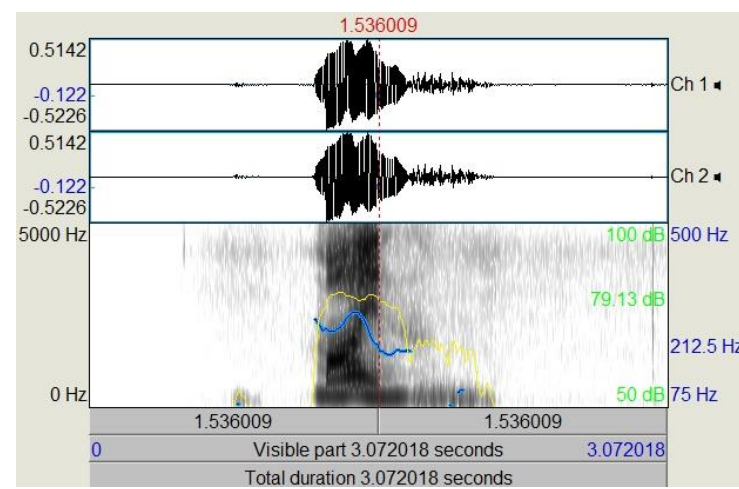

Gambar 25. Spectogram kata mine

4. Boy /oi/

Pada pengujar non-native, kata boy memiliki property pitch $301.0 \mathrm{~Hz}$ dan intensity $76.12 \mathrm{~dB}$.
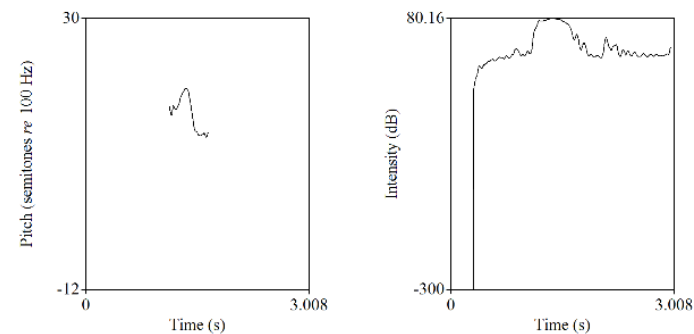

Gambar 26. Grafik untuk pitch dan intensity kata boy $(n N)$

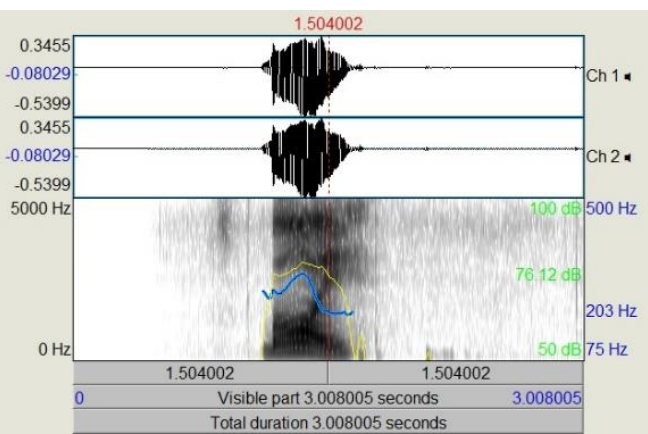

Gambar 27. Spectogram kata boy

5. Cure /oa/

Pada pengujar non-native, kata cure memiliki property pitch $202.9 \mathrm{~Hz}$ dan intensity $79.06 \mathrm{~dB}$.
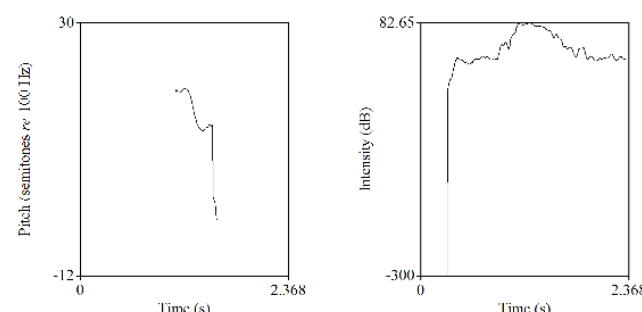

Gambar 28. Grafik untuk pitch dan intensity kata cure $(n N)$

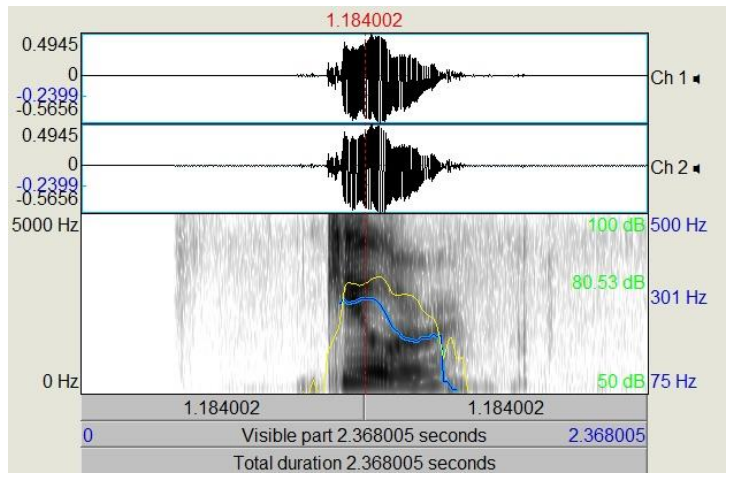

Gambar 29. Spectogram kata cure

Semua grafik dan spectrogram yang ditampilkan dalam penelitian ini diperoleh dengan pemrosesan data suara melalui ekstraktsi dan pengolahan data suara menggunakan program PRAAT. Setiap grafik memperlihatkan frekuensi dan intensitas suara pengujar; sementara spectrogram memperlihatkan seluruh variable data analisis beserta elemen-elemen pendukungnya, lengkap dengan tampilan pitch dan intensity pada tiap spectrogram. 


\section{SIMPULAN}

Secara keseluruhan, penelitian mengenai frekuensi dan intensitas suara ini memperlihatkan perbandingan hasil yang tersaji melalui tabel. Dari analisis yang diperoleh, memperlihatkan adanya kaitan antara diftong dan tinggi rendahnya pitch dan intensity dalam pengujaran kata-kata tersebut. Dapat disimpulkan bahwa pengujaran diftong dengan nilai pitch yang tertinggi baik dari pengujar native maupun non-native adalah ketika responden mengujarkan kata dengan diftong /oI/, yaitu kata boy dengan frekuensi suara $216.8 \mathrm{~Hz}$ untuk native dan $301.0 \mathrm{~Hz}$ untuk pengujar non-native. Hal ini dipengaruhi oleh huruf vokal terakhir mengalami peningkatan intonasi, sehingga pitch menjadi tinggi ketika mengucapkan kata tersebut.

Sedangkan untuk intensity, diftong /rə/ dalam kata here memiliki angka intensitas terbesar yaitu $78.36 \mathrm{~dB}$ untuk pengujar native dan $80.52 \mathrm{~dB}$ untuk pengujar nonnative. Berdasarkan pengambilan sampel data suara dari dua orang pengujar tersebut, maka dapat disimpulkan bahwa diftong /oI/ memiliki frekuensi yang tertinggi dibandingkan lainnya. Dan, diftong /ı/ memiliki angka intensitas tertinggi dibandingkan dengan diftong lainnya.

Tabel 3. Data perbandingan pitch dan intensity

\begin{tabular}{|c|c|c|c|c|c|c|c|}
\hline \multirow{2}{*}{$\begin{array}{c}\text { No } \\
\text {. }\end{array}$} & \multirow{2}{*}{$\begin{array}{c}\text { Dph } \\
\mathbf{t}\end{array}$} & \multirow{2}{*}{$\begin{array}{c}\text { Wor } \\
\text { d }\end{array}$} & \multirow{2}{*}{ Trns } & \multicolumn{2}{|c|}{ Pitch $(\mathbf{H z})$} & \multicolumn{2}{|c|}{$\begin{array}{c}\text { Intensity } \\
\text { (dB) }\end{array}$} \\
\hline & & & & $\mathbf{N}$ & $\mathrm{nN}$ & $\mathbf{N}$ & $\mathrm{nN}$ \\
\hline 1 & /eI/ & chair & $/ \mathrm{t} \varepsilon \mathrm{r} /$ & $\begin{array}{c}210 . \\
6\end{array}$ & $\begin{array}{c}204 . \\
9\end{array}$ & $\begin{array}{c}76.8 \\
5\end{array}$ & $\begin{array}{c}75.5 \\
2\end{array}$ \\
\hline 2 & /ı/ & here & /hir/ & $\begin{array}{c}189 . \\
2\end{array}$ & $\begin{array}{c}214 . \\
9\end{array}$ & $\begin{array}{c}78.3 \\
6\end{array}$ & $\begin{array}{c}80.5 \\
2\end{array}$ \\
\hline 3 & /aI/ & mine & $/ /$ main & $\begin{array}{c}211 . \\
4\end{array}$ & $\begin{array}{c}212 . \\
5\end{array}$ & 73.3 & $\begin{array}{c}79.1 \\
3\end{array}$ \\
\hline 4 & /oI/ & boy & /boi/ & $\begin{array}{c}216 . \\
8\end{array}$ & $\begin{array}{c}301 . \\
0\end{array}$ & $\begin{array}{c}71.3 \\
8\end{array}$ & $\begin{array}{c}76.1 \\
2\end{array}$ \\
\hline 5 & /ชə/ & cure & /kjor/ & $\begin{array}{c}188 . \\
1\end{array}$ & $\begin{array}{c}202 . \\
9\end{array}$ & $\begin{array}{c}75.7 \\
8\end{array}$ & $\begin{array}{c}79.0 \\
6\end{array}$ \\
\hline
\end{tabular}

Hasil perbandingan pada tabel di atas menunjukkan kecenderungan nilai yang hampir sama diantara kedua responden pada beberapa diftong yang diucapkan.

\section{REFERENSI}

[1] Aligarh, Agh., Hidayanto, Bekti Cahyo. (2016). Implementasi Metode Forensik dengan Menggunakan Pitch, Formant, dan Spectrogram untuk Analisis Kemiripan Suara Melalui Perekam Suara Telepon Genggam Pada Lingkungan yang Bervariasi. JURNAL TEKNIK ITS, Vol. 5, No. 2. ITS: Surabaya.

[2] Boersma, P., Weenink, D. (2014). PRAAT: doing phonetics by computer (Version 5.3.77). Amsterdam.

[3] Boersma, Paul., van Heuven, Vincent. (2001). Speak and unSpeak with PRAAT. Glot International Vol. 5, No.9/10. Blackwell: UK.
[4] Das, Kalyan. (2014). Production of Central Vowels and Centering Diphthongs by Assamese Speakers of English. Northeast Journal of Contemporary Research. India.

[5] Durao (Richards \&Weber). (2007). Contrastive approach in phonological disorders therapy: theoretical considerations. Rio de Janeiro Brasil.

[6] Gorjian, Bahman., Hayati, Abdolmajid. (2012). Using PRAAT Software In Teaching Prosodic Features To EFL Learners. 3rd World Conference on Psychology, Counselling and Guidance (WCPCG-2012). ELSEVIER.

[7] Hayward, K. (2000). Experimental Phonetics. London: Longman. Chs. 2-4.

[8] Jones, Daniel. (1972). The Pronunciation of English. London: Cambridge University Press

[9] M. N. Al-Azhar. (2001). Audio Forensic: Theory and Analysis. Pusat Laboratorium Forensik Polri Bidang Fisika dan KKomputer Forensik.

[10] Peterson, Stacey. (2016). Vowel Dispersion in English Diphthongs: Evidence from Adult Production. Proceedings of AMP 2015 Completed March 15, 2016

[11] Suyudi, Ichwan., Saptano, Debyo. (2016). Analisis Vocal Tract Pada Kajian Akustik Vokal Bahasa Indonesia. Prosiding PESAT (Psikologi, Ekonomi, Sastra, Arsitektur \&Teknik Sipil) Universitas Gunadarma - Depok - 20-21 Oktober 2015

[12] Tilman, Rosa da Costa., Nurhayani, Ika. (2015). Kesalahan Pengucapan Vokal Depan Bahasa Inggris Oleh Mahasiswa Semester I Universitas Nasionaltimor Lorosa'e. Jurnal LITE Vol. 11, No. 2. Universitas Dian Nuswantoro: Semarang.

[13] Van Lieshout, Pascal. (2003). PRAAT Short Tutorial A basic introduction. University of Toronto, Graduate Department of Speech Language Pathology, Faculty of Medicine, Oral Dynamics Lab V. 4.2.1, October 7, 2003 (PRAAT 4.1.x)

[14] Vogel, A. P., Maruff, P., Snyder, P. J., \& Mundt, J. C. (2009). Standardization of pitch-range settings in voice acoustic analysis. Behavior Research Methods, 41(2), 318-324.

[15] Wempe, Ton. (2009). PRAAT Script to Detect Syllable Nuclei and Measure Speech Rate Automatically. Behavior Research Methods 2009, 41 (2), 385-390

[16] Wilson, Ian. (2008). Using Praat and Moodle for Teaching Segmental and Suprasegmental Pronunciation. 2008 World CALL Proceeding. 